\title{
HEPATIC TUMORS : POSSIBLE RELATIONSHIP TO USE OF ORAL CONTRACEPTIVES
}

\author{
GERALD KLATSKIN ${ }^{1)}$ \\ Department of Medicine, Yale University, \\ New Haven, Connecticut, 06510, U.S.A. \\ (Received for publication February 1, 1977)
}

In 1970, Janet Baum submitted a paper to The Journal of the American Medical Association in which she suggested, on the basis of 3 cases, that oral contraceptives might be implicated in the development of hepatic tumors in young women (Baum, 1975). To her annoyance the editors rejected the paper with the comment that her suggestion was ridiculous! The first published paper to discuss the possible relationship between oral contraceptives and hepatic tumors, by Horvath et al. (Horvath et al., 1972), which appeared in 1972, attracted little attention. However, the report of 7 cases by Baum and her colleagues (Baum et al., 1973), which was published in Lancet in 1973, excited great interest and touched off an avalanche of similar case reports which continue to appear at an ever-increasing rate.

As shown in Table 1, the number of cases reported annually since 1973 has risen dramatically, so that by August 1976 there were at least 105 . In addition, 118 have been cited in the literature but not described, bringing the total to 223. As can be seen, most of the cases have been reported from the United
States. If, indeed, oral contraceptives do play a role in the pathogenesis of hepatic tumors, it may be anticipated that reports will begin to appear in increasing numbers from many other parts of the world where these agents are widely used. Moreover, if the present trend in reporting continues, hepatic tumors may prove to be a more serious problem than thromboembolic disease as a complication of oral contraceptive therapy.

Initially, the tumors encountered were benign, being variously classified as hepatic cell adenoma (Baum, 1975 ; Davis et al., 1973 ; Knapp and Ruebner, 1974 ; Vosnides et al., 1974 ; Bisson et al., 1974 ; Antoniades and Brooks, 1975 ;

Model et al., 1975 ; Ameriks et al., 1975 ; Block, 1975 ; Large, 1975 ; Clinicopathological Conference, 1975; Nissen and Kent, 1975 ; Antoniades et al., 1975 ; Edmondson et al., 1976 ; Baek et al., 1976 ; Littman et al., 1976; Schenken, 1976 ; Christopherson and Mays, 1976 ; Nissen et al., 1976), benign hepatoma (Horvath et al., 1972 ; Baum et al., 1973 ; Contostavlos, 1973 ; Kelso, 1974 ; Horvath et al., 1974 ; Tountas et al., 1974 ; Berg et al., 1974 ; Stenwing and Solgaard, 1975 ;

1) David Paige Smith Professor of Medicine, Dapartment of Medicine, Yale University, 333 Cedar Street, New Haven, Connecticut, 06510, U.S. A. 
TABLE 1

Hepatic tumors encountered in women using oral contraceptives

\begin{tabular}{c|r|r|r} 
& Case reports & $\begin{array}{c}\text { Cases Cited : } \\
\text { No Details }\end{array}$ & Total \\
\hline Year reported & & & \\
1972 & 1 & & 1 \\
1973 & 11 & & 11 \\
1974 & 14 & 90 & 14 \\
1975 & 31 & 28 & 121 \\
1976 & 48 & & 76 \\
& & & \\
Origin of reports & & 118 & 202 \\
United States & 84 & & 7 \\
United Kingdom & 7 & & 4 \\
Canada & 4 & & 1 \\
Sweden & 4 & & 1 \\
Hungary & 2 & & 1 \\
France & 1 & & 223 \\
Italy & 1 & & \\
Greece & 1 & & \\
Norway & 1 & & \\
\hline Total & 105 & & \\
\hline
\end{tabular}

TABLE 2

Types of hepatic tumor encountered in women using oral contraceptives

\begin{tabular}{l|c|c|c}
\hline & Case reports & $\begin{array}{c}\text { Cases Cited : } \\
\text { No Details }\end{array}$ & Total \\
\hline Diagnoses reported & & & \\
Hepatic cell adenoma & 52 & 41 & 93 \\
Benign hepatoma & 17 & & 17 \\
Focal nodular hyperplasia & 19 & 61 & 80 \\
Hamartoma & 71 & 7 & 14 \\
Malignant hepatic tumor & 10 & 9 & 19 \\
\hline Current diagnostic classification & & & \\
Benign tumors & & & $110(49 \%)$ \\
$\quad$ Hepatic cell adenoma & 69 & 68 & $94(42 \%)$ \\
$\quad$ Focal nodular hyperplasia & 26 & 9 & $17(8 \%)$ \\
Malignant tumors & & & $1(0.4 \%)$ \\
$\quad$ Hepatocellular carcinoma & 8 & 1 & $1(0.4 \%)$ \\
$\quad$ Hepatoblastoma & 1 & & 223 \\
$\quad$ Mixed hepatocellular-ductular & 105 & 118 & \\
\hline$\quad$ Total & & & \\
\hline
\end{tabular}


Galloway et al., 1975 ; Hauschild, 1975), focal nodular hyperplasia (Nissen and Kent, 1975 ; Mays et al., 1974 ; Fisher et al., 1975 ; Shojania and Hogg, 1975 ;

Stauffer et al., 1975 ; Grabowski et al., 1975 ; Mays et al., 1976 ; Ross et al., 1976 ; Christopherson et al., 1975 ;

Christopherson, 1975 ; Christopherson and Mays, 1976 ; Nissen et al., 1976) or hamartoma (Mays et al., 1976 ; Bartók et al., 1976 ; O'Sullivan and Wilding, 1974 ; Nissen et al., 1976). However, more recently, malignant tumors of several types have been reported, including hepatocellular carcinoma (Mays et al., 1976 ; Hermann and David, 1973 ; Davis et al., 1975 ; Glassberg and Rosenbaum, 1976 ; Tigano et al., 1976 ; Christopher- son, 1975 ; Christopherson and Mays, 1976), mixed hepatocellular and ductular carcinoma (O'Sullivan and Rosswick, 1976) and hepatoblastoma (Meyer et al., 1974) (Table 2). Since there is general agreement (Edmondson, 1958; Ishak and Rabin, 1975) that hepatic cell adenoma and benign hepatoma on the one hand, and focal nodular hyperplasia and hamartoma on the other, are synonymous, I have, for the purposes of this discussion, regrouped the benign tumors under discussion into two categories, hepatic cell adenoma and focal nodular hyperplasia.

As can be seen in Table 3, over half the patients had used oral contraceptives for more than 5 years. However,

TABLE 3

Use of oral contraceptives by women with hepatic tumors

\begin{tabular}{|c|c|c|c|c|}
\hline & $\begin{array}{l}\text { Hepatic cell } \\
\text { adenoma } \\
(69 \text { cases })\end{array}$ & $\begin{array}{c}\text { Focal nodular } \\
\text { hyperplasia } \\
(26 \text { cases })\end{array}$ & $\begin{array}{l}\text { Malignant } \\
(10 \text { cases })\end{array}$ & $\begin{array}{c}\text { Total } \\
\text { (105 cases })\end{array}$ \\
\hline \multicolumn{5}{|l|}{ Years } \\
\hline$<1$ & 8 & 2 & 1 & $11(11 \%)$ \\
\hline $1-5$ & 19 & 10 & 7 & $36(36 \%)$ \\
\hline$>5$ & 37 & 13 & 2 & $52(53 \%)$ \\
\hline \multicolumn{5}{|l|}{ Type employed } \\
\hline \multicolumn{5}{|l|}{ Mestranol, plus: } \\
\hline norethynodrel & 6 & 6 & 1 & 13 \\
\hline norethindrone & 8 & 8 & & 16 \\
\hline lynestrenol & 1 & 3 & 1 & 5 \\
\hline ethynodiol & & 5 & & 5 \\
\hline chlormadinone & 1 & & & 1 \\
\hline norethisterone & & 2 & 1 & 3 \\
\hline progestagen type ? & 29 & & & 29 \\
\hline \multicolumn{5}{|l|}{ Ethinyl estradiol, plus: } \\
\hline dimethisterone & 1 & & & 1 \\
\hline norgestrel & 4 & 1 & 2 & 7 \\
\hline norethindrone & 1 & & & 1 \\
\hline progestagen type? & 2 & & & 2 \\
\hline
\end{tabular}

Total 
in 11 percent of the cases, the period of exposure had been as brief as 6 to 12 months. Moreover, in 8 patients, the tumor had not become apparent until 6 months to 10 years following withdrawal of oral contraceptives (Davis et al., 1973 ; Bisson et al., 1974 ; Antoniades and Brools, 1975 ; Model et al., 1975 ; Nissen and Kent, 1975 ; Stenwing and Solgaard, 1975 ; Mays et al., 1974 ; Fisher et al., 1975 ; Grabowski et al., 1975).

The contraceptive agents employed in this group included almost all combinations of synthetic estrogens and progestagens in common use (Table 3 ). However, it will be noted that those containing mestranol as the estrogen outnumbered those containing ethinyl estradiol. Edmondson (Edmondson et al., 1976) have proposed that mestranol has a greater oncogenic potential than ethinyl estradiol. However, this view is open to question, since, as pointed out by ohers (Barnes, 1976 ; Evrard, 1976), mestranol has been in use significantly longer than ethinyl estradiol, so that women on oral contraceptives for over 5 years were more likely to have received mestranol.

TABLE 4

Presenting complaints in women with benign hepatic tumors possibly related to use of oral contraceptives

\begin{tabular}{l|r|r|r}
\hline & $\begin{array}{c}\text { Hepatic cell } \\
\text { adenoma } \\
(69 \text { cases })\end{array}$ & $\begin{array}{c}\text { Focal nodular } \\
\text { hyperplasia } \\
(26 \text { cases })\end{array}$ & $\begin{array}{c}\text { Total } \\
\text { (95 cases) }\end{array}$ \\
\hline Acute abdominal pain, shock & $30(43 \%)$ & $4(15 \%)$ & $34(36 \%)$ \\
$\quad$ Tumor rupture, hemoperitoneum & $18(26 \%)$ & $2(8 \%)$ & $20(21 \%)$ \\
$\quad$ Tumor hemorrhage & $16(23 \%)$ & $4(15 \%)$ & $20(21 \%)$ \\
Palpable mass & $1(1 \%)$ & $4(15 \%)$ & $5(5 \%)$ \\
Chronic or intermittent pain & $1(1 \%)$ & 0 & 1 \\
Hepatomegaly & $3(4 \%)$ & $12(46 \%)$ & $15(15 \%)$ \\
Asymptomatic : tumor an unexpected & & & \\
$\quad$ finding at laparotomy & & &
\end{tabular}

As shown in Table 4, in patients with hepatic cell adenomas, the major presenting complaint in over two-thirds of the group was acute abdominal pain usually accompanied by shock, due to either rupture of the tumor with hemoperitoneum or hemorrhage into the tumor, and, in almost a quarter of the group, it was a palpable mass that drew attention to the tumor. In contrast, in patients with focal nodular hyperplasia, almost half had asymptomatic tumors that were discovered unexpectedly during laparotomy for other un- related diseases. Nevertheless, almost a quarter of the patients also presented with acute abdominal pain attributable to rupture of the tumor with hemoperitoneum or hemorrhage into the tumor.

Except for the absence of cirrhosis in all cases, the clinical features in patients with malignant hepatic tumors associated with the use of oral contraceptives were similar to those that usually accompany such tumors, so that they will not be discussed further.

Hepatic function was remarkably well 
preserved even when the tumors were large. Thus, minor elevations in serum bilirubin, alkaline phosphatase and transaminase were found in only a minority of the cases tested (Table 5).

As shown in Table 5, technetium sulfur-colloid scans of the liver revealed defects in most but not all cases of hepatic cell adenoma and focal nodular hyperplasia. As might be anticipated, all tumors smaller than $4 \mathrm{~cm}$ in dia- meter escaped detection. The defects did not appear to depend on the presence within the tumor of fibrosis, hemorrhage or necrosis, suggesting that they reflected either impairment of reticuloendothelial phagocytic function or a reduction in blood flow. Observations in one of our own cases clearly demonstrated that the defect was attributable to failure of the reticuloendothelium to take up colloid.

TABLE 5

Functional, scintiscan and arteriographic findings in women with hepatic tumors associated with the use of oral contraceptives

\begin{tabular}{|c|c|c|c|c|}
\hline & $\begin{array}{l}\text { Hepatic cell } \\
\text { adenoma }\end{array}$ & $\begin{array}{l}\text { Focal nodular } \\
\text { hyperplasia }\end{array}$ & \multicolumn{2}{|c|}{ Total } \\
\hline \multicolumn{5}{|l|}{ Hepatic functional abnormalities } \\
\hline Serum bilirubin & $1 / 13$ & $0 / 3$ & $1 / 16$ & $(6 \%)$ \\
\hline Serum alkaline phosphatase & $2 / 12$ & $1 / 3$ & $3 / 15$ & $(20 \%)$ \\
\hline Serum transaminase & $5 / 13$ & $0 / 3$ & $5 / 16$ & $(31 \%)$ \\
\hline$\alpha$-fetoprotein & $0 / 7$ & $0 / 2$ & $0 / 19$ & \\
\hline \multicolumn{5}{|l|}{ Hepatic scintiscan defects } \\
\hline Patients & $10 / 14$ & $6 / 6$ & $16 / 20$ & $(80 \%)$ \\
\hline Tumors & $14 / 17$ & $7 / 9$ & $21 / 26$ & $(81 \%)$ \\
\hline Tumor $1-3 \mathrm{~cm}$ & $0 / 3$ & $0 / 2$ & $0 / 5$ & \\
\hline Tumor $>3 \mathrm{~cm}$ & $11 / 14$ & $7 / 7$ & $18 / 21$ & $(86 \%)$ \\
\hline Tumor fibrosis & $2 / 5$ & $4 / 5$ & $6 / 10$ & $(60 \%)$ \\
\hline No fibrosis & $10 / 12$ & $3 / 4$ & $13 / 16$ & $(81 \%)$ \\
\hline Tumor hemorrhage & $8 / 11$ & $4 / 4$ & $12 / 15$ & $(80 \%)$ \\
\hline No hemorrhage & $3 / 6$ & $3 / 5$ & $6 / 11$ & $(55 \%)$ \\
\hline Tumor necrosis & $6 / 6$ & $3 / 3$ & $9 / 9$ & $(100 \%)$ \\
\hline No necrosis & $5 / 11$ & $4 / 6$ & $9 / 17$ & $(53 \%)$ \\
\hline \multicolumn{5}{|l|}{ Arteriographic abnormalities } \\
\hline Patients & $14 / 14$ & $4 / 6$ & $18 / 20$ & $(90 \%)$ \\
\hline Tumors & $16 / 18$ & $5 / 7$ & $21 / 25$ & $(84 \%)$ \\
\hline Enlarged hepatic artery & $7 / 16$ & $0 / 5$ & $7 / 21$ & $(33 \%)$ \\
\hline Peripheral arterial supply & $8 / 16$ & $1 / 5$ & $9 / 21$ & $(43 \%)$ \\
\hline Increased vascularity & $12 / 16$ & $4 / 5$ & $16 / 21$ & $(76 \%)$ \\
\hline Avascularity & $1 / 16$ & $0 / 5$ & $1 / 21$ & $(5 \%)$ \\
\hline Tumor "blush" & $7 / 16$ & $1 / 5$ & $8 / 21$ & $(38 \%)$ \\
\hline
\end{tabular}

As can be seen in Fig. 1, the technetium sulfur-colloid scan in this patient revealed a large defect in the left lobe. However, as shown in Fig. 2, the tumor incorporated selenomethionine as well as normal liver tissue, demon- 
strating the integrity of its hepatocellular synthetic function. Similarly, blood flow through the tumor was not impaired as evidenced by the normal distribution of isotope following an in-

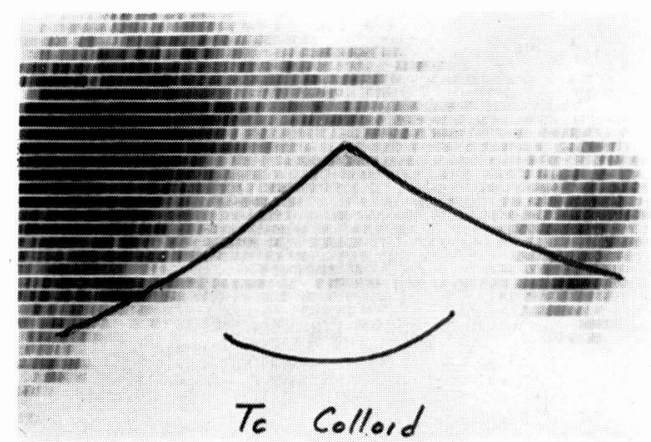

Fig. 1

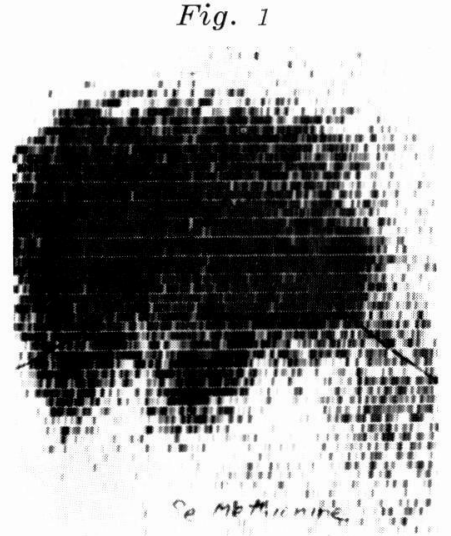

Fig. 2

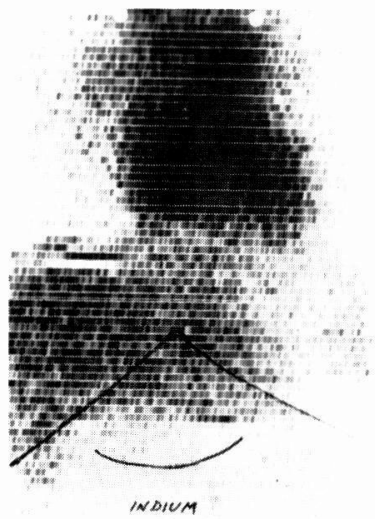

Fig. 3 travenous injection of acid indium-113m (Fig. 3).

Arteriographic abnormalitities were demonstrable in most but not all of the tumors investigated (Table 5). As previously pointed out by Goldstein et al. (Goldstein et al., 1974), the findings in hepatic cell adenoma and focal nodular hyperplasia were indistinguishable. The principal features included enlargement of the hepatic artery, a peripheral arterial blood supply, increased vascularity, and a tumor blush during the venous phase. Rarely, the tumor appeared avascular due to intramural hemorrhage, necrosis or infarction.

Fig. 4 illustrates the arched peripheral arterial blood supply outlining a large area of focal nodular hyperplasia in the

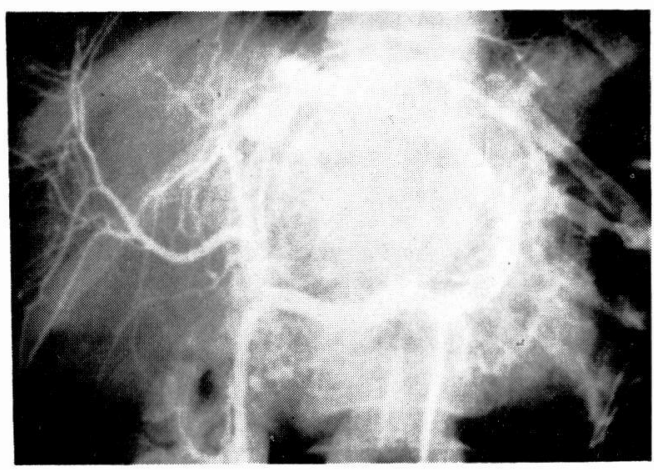

Fig. 4

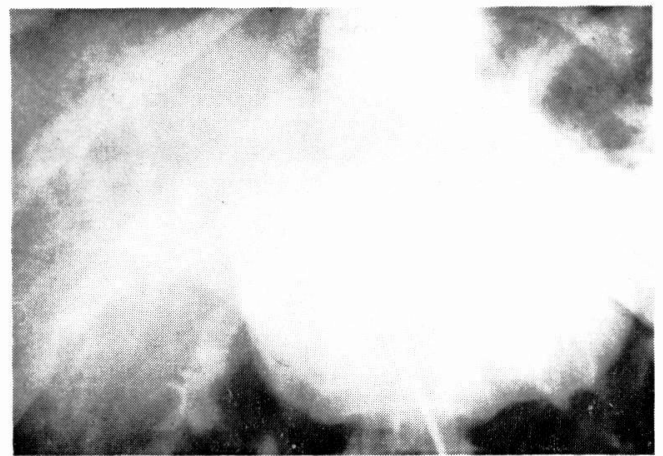

Fig. 5 
left lobe of the liver. During the venous phase, as shown in Fig. 5 , the tumor was deeply stained, clearly outlining its contour, and sharply demarcating it from the surrounding normal liver.

Long-term followup data on the clinical course are available in only a minority of the patients with hepatic tumors associated with the use of oral contraceptives (Table 6). However, of the 95 with hepatic cell adenomas or focal nodular hyperplasia, 87 (92\%) were still alive at the time of reporting, 2 months to 6 years following the detection of the tumor. All 8 deaths occurred in patients with hepatic cell adenomas, and were attributable to rupture with hemoperitoneum in 7
(Baum et al., 1973 ; Vosnides et al., 1974 ; Clinicopathological Conference, 1975 ; Contostavlos, 1973 ; Kelso, 1974 ; Berg et al., 1974), and intramural hemorrhage in 1 (Knapp and Ruebner, 1974). Of those who died, 4 had undergone lobectomy or resection of the tumor (Baum et al., 1973 ; Knapp and Ruebner, 1974 ; Kelso, 1974 ; Berg et al., 1974), 1 had been subjected to packing and suture of a ruptured tumor followed by hepatic artery ligation (Vosnides et al., 1974 ; Clinicopathological Conference 1975), and 3 had died of tumor rupture and hemoperitoneum before surgical treatment could be instituted (Contostavlos, 1973 ; Berg et al., 1974).

TABLE 6

Clinical course of women with benign hepatic tumors associated with the use of oral contraceptives

\begin{tabular}{|c|c|c|}
\hline Survived & $87 / 95$ & $(92 \%)$ \\
\hline Died & & \\
\hline Following surgery & & \\
\hline Resection & $4 / 82$ & $(5 \%)$ \\
\hline Packing or drainage & $1 / 3$ & $(33 \%)$ \\
\hline Biopsy & $0 / 5$ & \\
\hline No surgery & $3 / 5$ & $(60 \%)$ \\
\hline Total & $8 / 95$ & $(8 \%)$ \\
\hline Progression of unresected tumors & $0 / 9$ & \\
\hline Regression of unresected tumors & $3 / 9$ & $(33 \%)$ \\
\hline Malignant transformation of unresected tumors & $0 / 9$ & \\
\hline Development of new tumor following resection & $1 / 82$ & $(1 \%)$ \\
\hline
\end{tabular}

Surgery was remarkably well tolerated in this group, the survival rate being $95 \%$ in the 82 subjected to resection or lobectomy, $67 \%$ in the 3 whose tumors were packed, drained and/or sutured, and $100 \%$ in the 5 with relatively small nonhemorrhagic tumors subjected to biopsy alone.

Of the 3 survivors with hepatic cell adenomas that were not resected (Model et al., 1975 ; Ameriks et al.,1975 ; Galloway et al., 1975) only one (Galloway et al., 1975) had a large hemorrhagic tumor that required drainage. Withdrawal of oral contraceptives in this case was followed by a marked reduction in the size of the tumor over a period of 15 months, as documented by angiography. Similarly, in 2 (Stauffer et al., 1975 ; Ross et al., 1976) of the 6 with focal 
nodular hyperplasias that were left in situ (Nissen and Kent, 1975 ; Fisher et al., 1975 ; Stauffer et al., 1975 ; Mays et al., 1976 ; Ross et al., 1976 ; O'Sullivan and Wilding, 1974), withdrawal of oral contraceptives was followed by regression of the tumors. One of these tumors, which was massive in size and contained a large hematoma requiring drainage, was found on scan to be significantly smaller 3 months later (Stauffer et al., 1975). The other (Ross et al., 1976), also large and located in the right lobe could not be removed because of the presence in the left lobe of a similar tumor that had ruptured necessitating lobectomy. Over a period of 18 months, there was significant shrinkage of the tumor left in situ, as documented by serial scanning. Followup scintiscanning and arteriography were not carried out at the time of reporting in 6 of the survivors with tumors left in situ. However, all were well clinically, and none showed clinical evidence of progression or malignant transformation over periods ranging from 5 to 10 months.

None of the 82 resected tumors recurred. However, in a patient who continued to use oral contraceptives following a left lobectomy for hemorrhagic focal nodular hyperplasia, a similar large tumor appeared in the right lobe 6 years later (Mays et al., 1976). The tumor, which was biopsied, was left in situ and oral contraceptives were discontinued. Five months later there was clinical evidence that the tumor had regressed in size.

The prognosis in patients with malignant hepatic tumors associated with the use of oral contraceptives appeared to be as poor as in those who have not used such agents. Thus, of the $10 \mathrm{pa}-$ tients reported, 5 have died, including one with hepatocellular carcinoma whose death occurred during the course of a lobectomy (Mays et al., 1976), one with untreated hepatocellular carcinoma who died in 4 months (Tigano et al., 1976), 2 with untreated hepatocellular carcinoma whose duration of survival has not been reported (Mays et al., 1976) and one with a hepatoblastoma who survived for a year following lobectomy (Meyer et al., 1974; Klatskin). Of the 5 patients who were still alive at the time of reporting, 2 with hepatocellular carcinoma were well clinically one year following lobectomy (Hermann and David, 1973 ; Davis et al., 1975) and another for a period of 2 months following lobectomy (Mays et al., 1976). The duration of survival in the 2 remaining patients, one with a mixed hepatocellular and ductular carcinoma treated with hepatic artery ligation and chemotherapy (O'Sullivan and Rosswick, 1976), and another with hepatocellular carcinoma given chemotherapy alone (Glassberg and Rosenbaum, 1976), has not been reported.

The relatively long survival following resection in the 2 cases of hepatocellular carcinoma cited (Hermann and David, 1973 ; Davis et al., 1975), invites speculation that withdrawal of oral contraceptives alone could conceivably lead to regression of such tumors.

According to authoritative sources (Edmondson, 1958; Ishak and Rabin, 1975), hepatic cell adenoma and focal nodular hyperplasia are unrelated tumors, each with distinctive morphological features, that show no tendency to undergo malignant transformation. It is surprising, therefore, that, if oral contraceptitives are implicated in the pathogenesis of hepatic tumors, they produce lesions of such diverse structure and biological behavior. This raises two questions : first, do currently accepted morphological criteria clearly distinguish between hepatic cell adenoma and focal nodular hyperplasia, and, 
second, is it conceivable, at least under conditions of oral contraceptive therapy, that hepatic cell adenoma and focal nodular hyperplasia reprepresent two phases in the development of the same lesion, and that such lelions may undergo malignant transformation?

Hepatic cell adenoma usually presents as a solitary, relatively soft, sharply circumscribed, unencapsulated mass of variable size just beneath Glisson's capsule. Multiple tumors are not rare, and, occasionally, they are pedunculated, as seen in Fig. 6. On cross-section, the tumor is lighter in color than the adjacent intact liver, has a fleshy appearance and may show foci of hemorrhage, as illustrated in Fig. 7. The cut surface may show ill-defined lobulation, but is never frankly nodular and fibro-

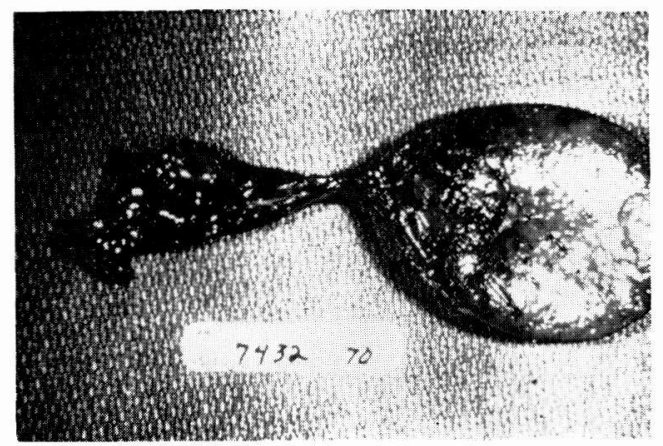

Fig. 6

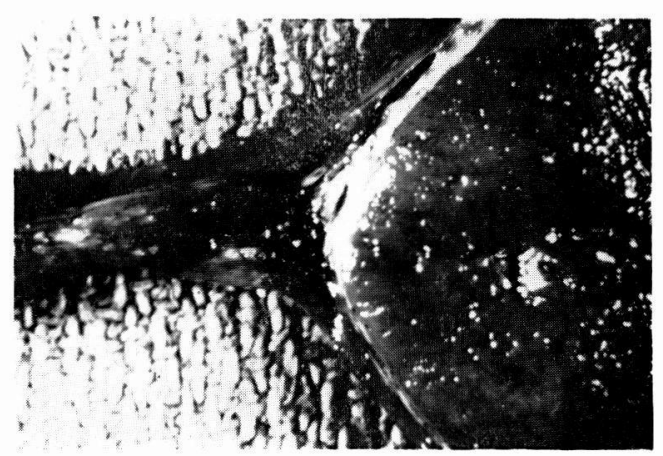

Fig. 7 tic. Microscopically, the neoplastic cells closely resemble normal hepatocytes, and show no features suggestive of malignancy (Fig. 8). However, particularly at the periphery of the tumor, they may be larger and paler than normal hepatocytes, due to increased de-

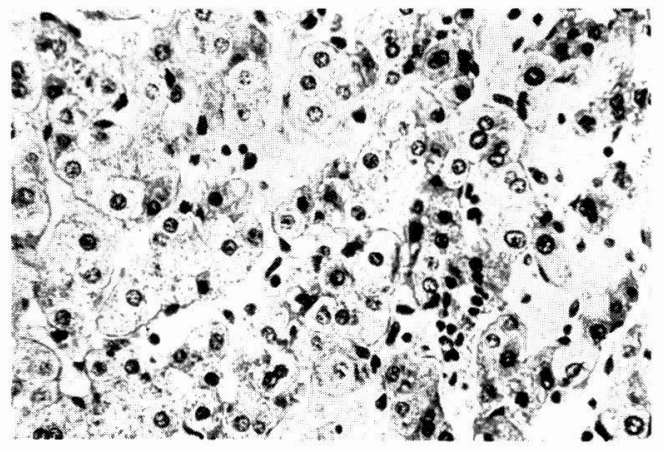

Fig. 8

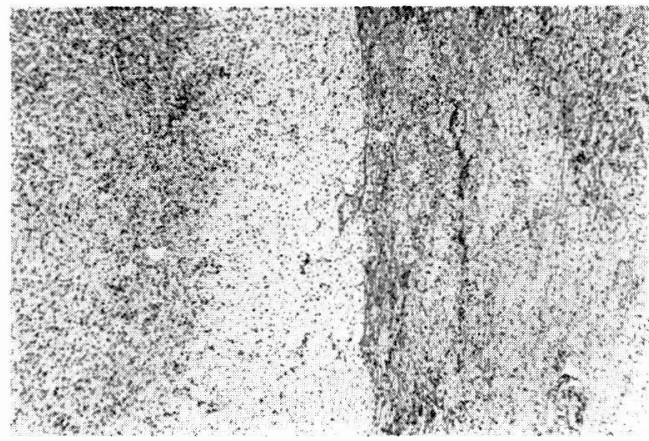

Fig. 9

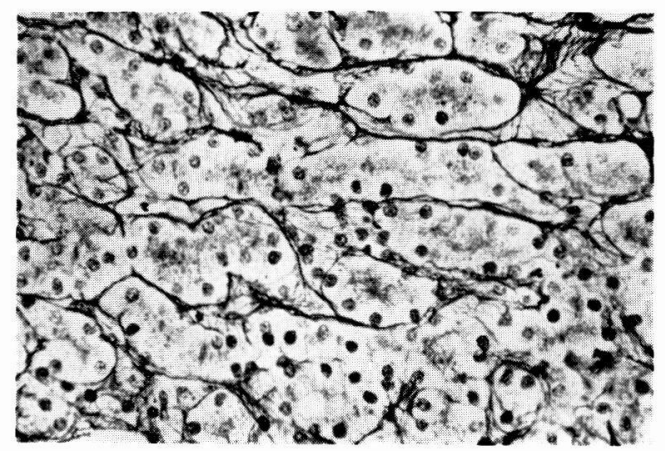

Fig. 10 
posion of glycogen (Fig. 9), and often, as shown in Fig. 10, are arranged in the form of thick plates, rosettes or pseudoducts, some of which may contain bile thrombi (Fig. 11). Deeper in the tumor, the neoplastic cells tend to be smaller and darker, and of ten show

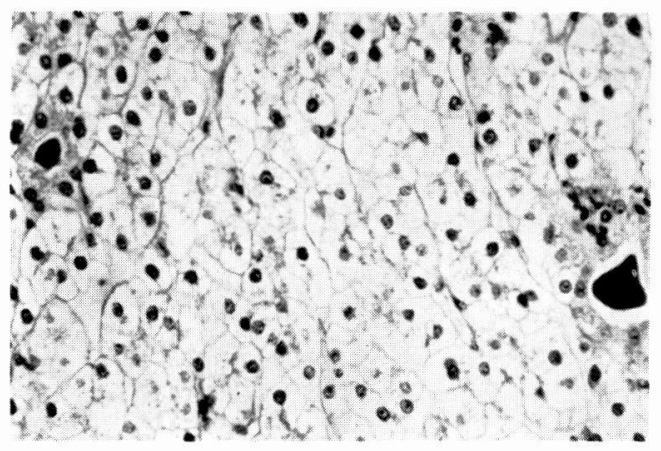

Fig. 11

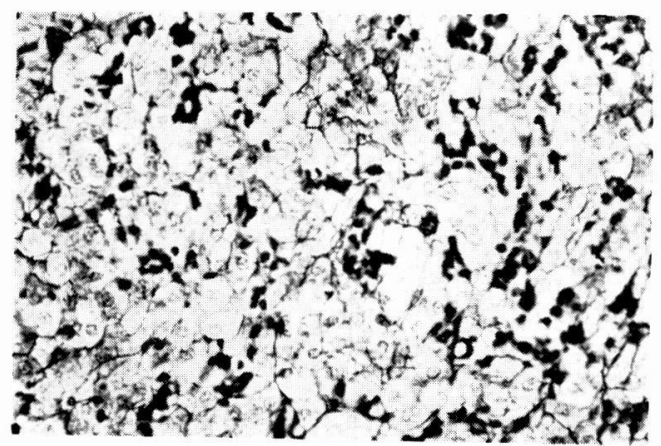

Fig. 12

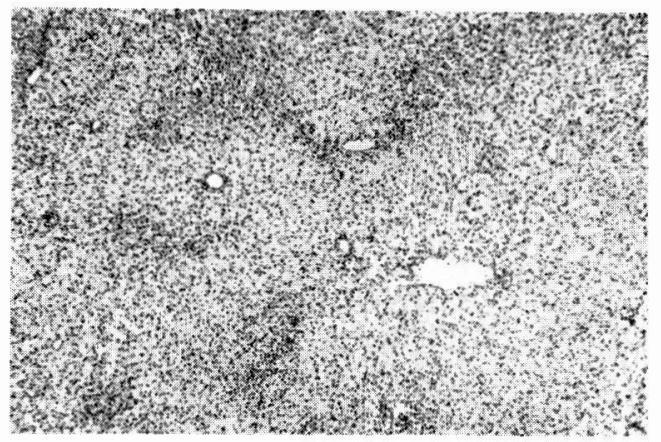

Fig. 13 an irregular interrupted plate pattern with an unusually delicate imperfectly developed reticulin network (Fig. 12). Frequently, the tumor contains numerous vessels resembling central veins, but few or no normal portal triads or interlobular bile ducts (Fig. 13). The sinusoids are normal in some areas, but may be collapsed or dilated in others.

In contrast to hepatic cell adenoma, focal nodular hyperplasia presents as a firm, grossly nodular mass of variable size, which on cross-section characteristically contains a large stellate fibrous core with radiating branching septa that subdivide the tumor into nodules (Fig. 14). Microscopically, the

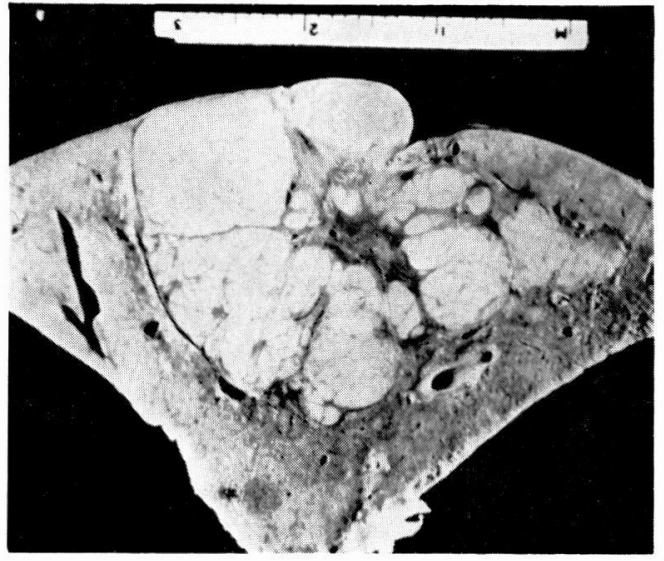

Fig. 14

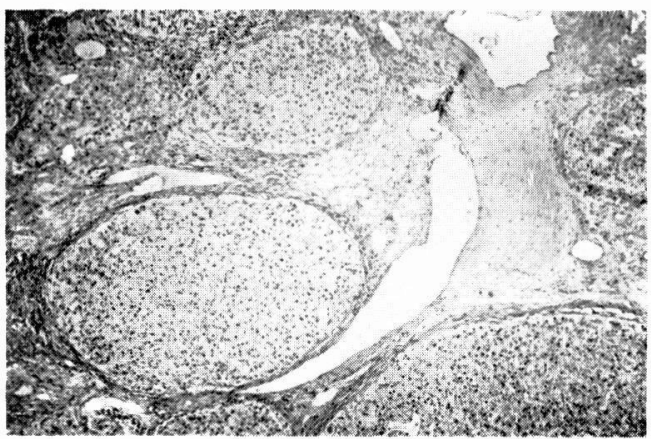

Fig. 15 
lesion closely resembles that of an inactive cirrhosis (Fig. 15). Characteristically, the fibrous septa contain numerous blood vessels, ductules and mononuclear inflammatory cells, as shown in Fig. 16. In some cases, the large



Fig. 16

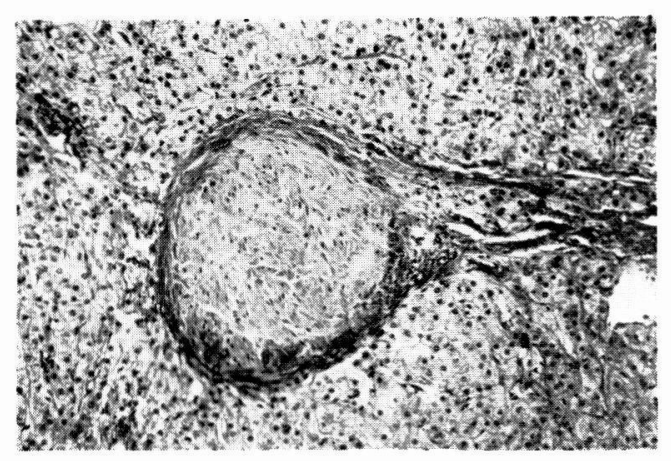

Fig. 17

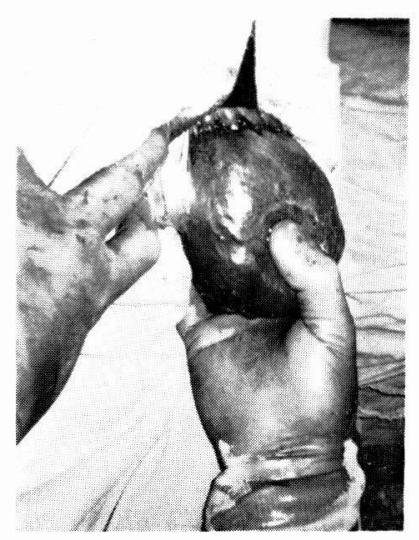

Fig. 18 vessels are thickened as a result of subintimal fibrosis or hypertrophy of the media, occasionally leading to obliteration of their lumens, as illustrated in Fig. 17.

In the two cases just presented, the usually accepted morphological criteria (Edmondson, 1958; Ishak and Rabin, 1975), clearly differentiated between hepatic cell adenoma and focal nodular hyperplasia. However, it is evident from the literature and $\mathrm{my}$ own experience that they do not do so in all cases. No doubt this accounts for much of the confusion and disagreement over the classification of the benign hepatic tumors encountered both in patients on oral contraceptives and in those with no exposure to such agents. Fig. 18 illu-

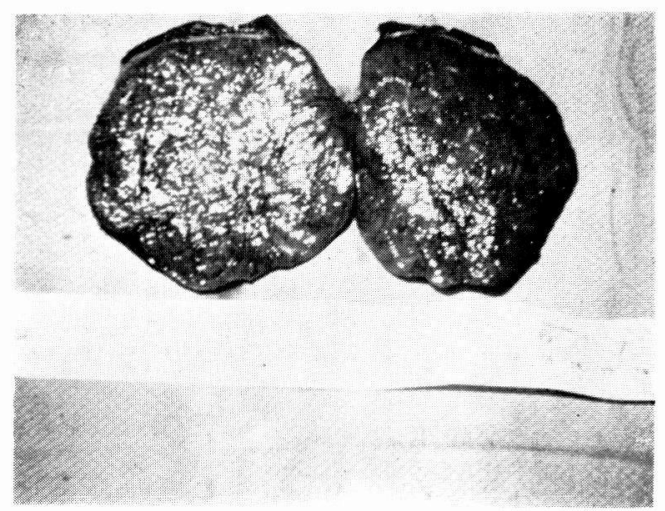

Fig. 19

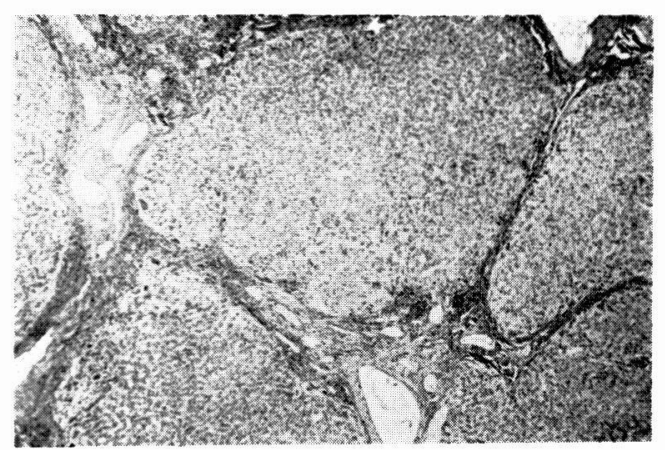

Fig. 20 
strates a large relatively soft unencapsulated tumor projecting from the left lobe of the liver. On cross-section, as shown in Fig. 19, the tumor was fleshy and pale in appearance and showed no evidence of a fibrous core or nodulation, features strongly suggesting that it was a hepatic cell adenoma. However, microscopically, as shown in Fig. 20, it had the typical fibronodular structure of focal nodular hyperplasia.

Illustrated in Fig. 21 is a large soft tumor removed from the left lobe of the liver. On cross-section, it was pale and unencapsulated and showed areas of ischemic necrosis and hemorrhage, but no central fibrous core or frank nodulation (Fig. 22). Microscopically, it had all the typical features of a hepatic cell adenoma. However, in addi-



Fig. 21

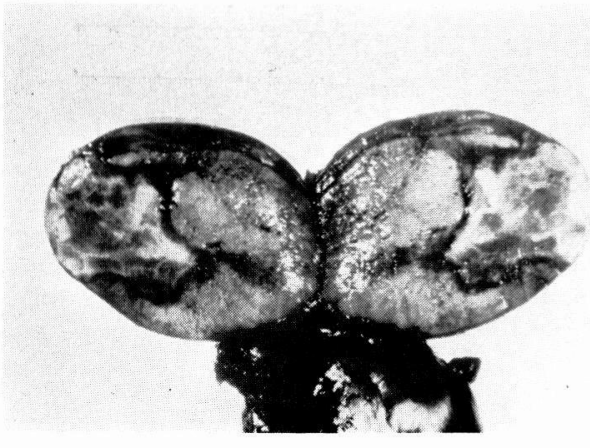

Fig. 22 tion, as can be seen in Fig. 23, the section was traversed by septa which outlined coarse nodules not evident on gross inspection, suggesting the possibility of focal nodular hyperplasia. However, as is evident from this trichrome-stained section, the septa were

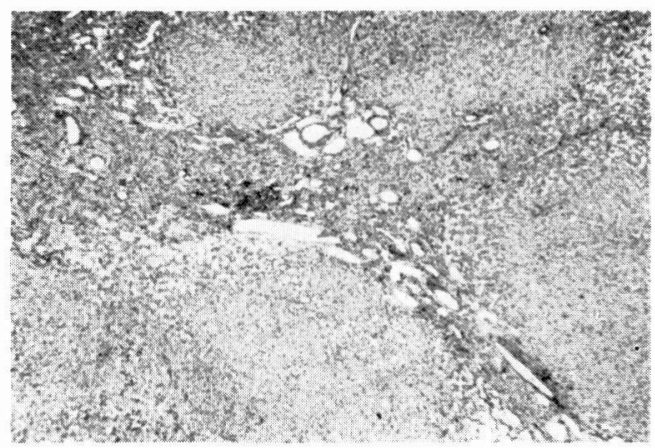

Fig. 23

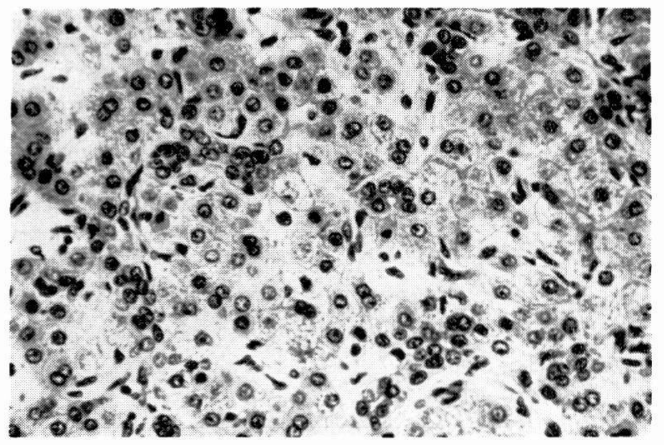

Fig. 24

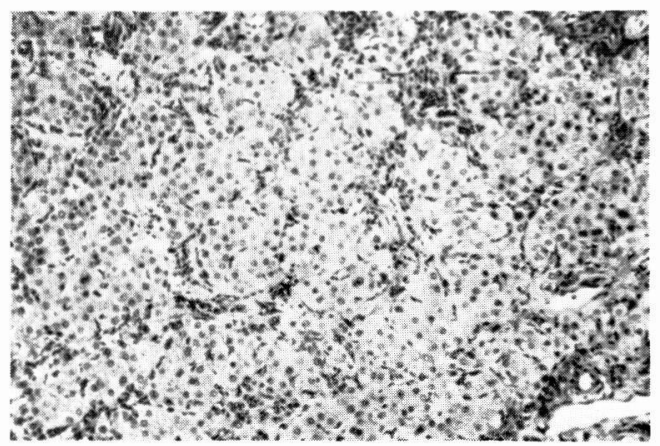

Fig. 25 
not collagenized, as would be expected in focal nodular hyperplasia, but instead contained numerous neoplastic cells, ductules and blood vessels. At higher magnification (Fig. 24), it can be seen that the bulk of the septum was made up of tightly packed masses of small neoplastic cells interspersed with numerous ductules. In a few areas, however, as shown in Fig. 25, the septal tumor cells had a delicate fibrous stroma containing a few minute vessels and ductules.

The last 2 cases presented illustrate the fact that currently accepted morphological criteria do not always clearly distinguish between hepatic cell adenoma and focal nodular hyperplasia, and suggest the possibility that, at least in some cases, these two types of tumor may be related. Conceivably, focal nodular hyperplasia represents a sequela of antecedent hepatic cell adenoma, or, alternatively, the stimulus for tumor growth affects entodermal and mesenchymal elements in the liver to a variable degree in different tumors.

There is no convincing evidence that hepatic cell adenomas or focal nodular hyperplasia undergo malignant transformation. However, Galloway et al. (Galloway et al., 1975) contend that many recently reported cases of hepatic cell adenoma show hepatocellular atypia, and should be regarded as precancerous and classified as "minimal deviation hepatomas." Unfortunately, they present no convincing evidence to support this view.

In considering the behavior of the hepatic tumors encountered in women on oral contraceptives, their propensity to rupture and bleed appears to be greater than that previously reported in nonusers of such agents (Edmondson, 1958 ; Ishak and Rabin, 1975). This raises the question whether or not oral contraceptives modify the morphological and clinical features of hepatic cell adenomas and focal nodular hyperplasia. A comparison of the clinical and morphological features of benign hepatic tumors in patients with and without exposure to oral contraceptives should give some indication of whether or not such agents affect the behavior of the tumors, even if the classification of some lesions in both groups is open to question. For purposes of comparison with oral contraceptive-associated tumors, I have culled from the literature 138 cases of hepatic cell adenoma (Davis et al., 1973 ; Edmondson et al., 1976 ; Schenken, 1976 ; Berg et al., 1974 ; Galloway et al., 1975 ; Grabowski et al., 1975 ; Hermann and David, 1973 ; Ishak and Rabin, 1975 ; Wilens, 1938 ; Packard and Stevenson, 1944 ; Duckett and Montgomery, 1947 ; Stumpf and Liber, 1954 ; Henson et al., 1956 ; Jager and Nugent, 1958 ; Berkheiser, 1959 ; Longiadér, 1963 ; Palubinskas et al., 1967 ; Scorer, 1969 ; Garancis et al., 1969 ; Malt et al., 1970 ; Kay and Schatzki, 1971; Motsay and Gamble, 1972 ; Phillips et al., 1973 ; Albritton et al., 1974 ; Goldstein et al., 1974) and 234 cases of focal nodular hyperplasia (Fisher et al., 1975 ; Shoiania and Hongg, 1975 ; Grabowski et al., 1975 ; Ishak and Rabin, 1975 ; Longmire and Marable, 1961; Malt et al., 1970 ; Phillips et al., 1973 ; Goldstein et al., 1974 ; Schrager, 1937 ; Hoffman, 1942 ; Benson and Pemberthy, 1942 ; Franklin and Dowling, 1947 ; Hunter, 1949 ; Kay and Talbert, 1950 ; McBurney et al., 1950 ; Gerding et al., 1951 ; Begg and Berry, 1953 ; Benz and Baggenstoss, 1953 ; Ramchand et al., 1970 ; Whelan et al., 1973 ; McMullen et al., 1973 ; McLoughlin et al., 1973) found in patients with no history of exposure to oral contraceptives. 
In considering the clinical differences between hepatic cell adenomas in users and nonusers of oral contracepti- ves (Table 7), it is noteworthy that $10 \%$ of the nonusers were male, and over a third were either below or above

TABLE 7

Hepatic cell adenomas: Comparison of features in women on oral contraceptives and in patients with no reported use of such agents




the child-bearing age. Of greater significance, acute abdominal pain, due to either tumor rupture and hemo- peritoneum or hemorrhage into the tumor, was the presenting complaint in 3 times as many "pill"-users as no-

TABLE 8

Focal nodular hyperplasia: Comparison of features in women on oral contraceptives and in patients with no reported use of such agents

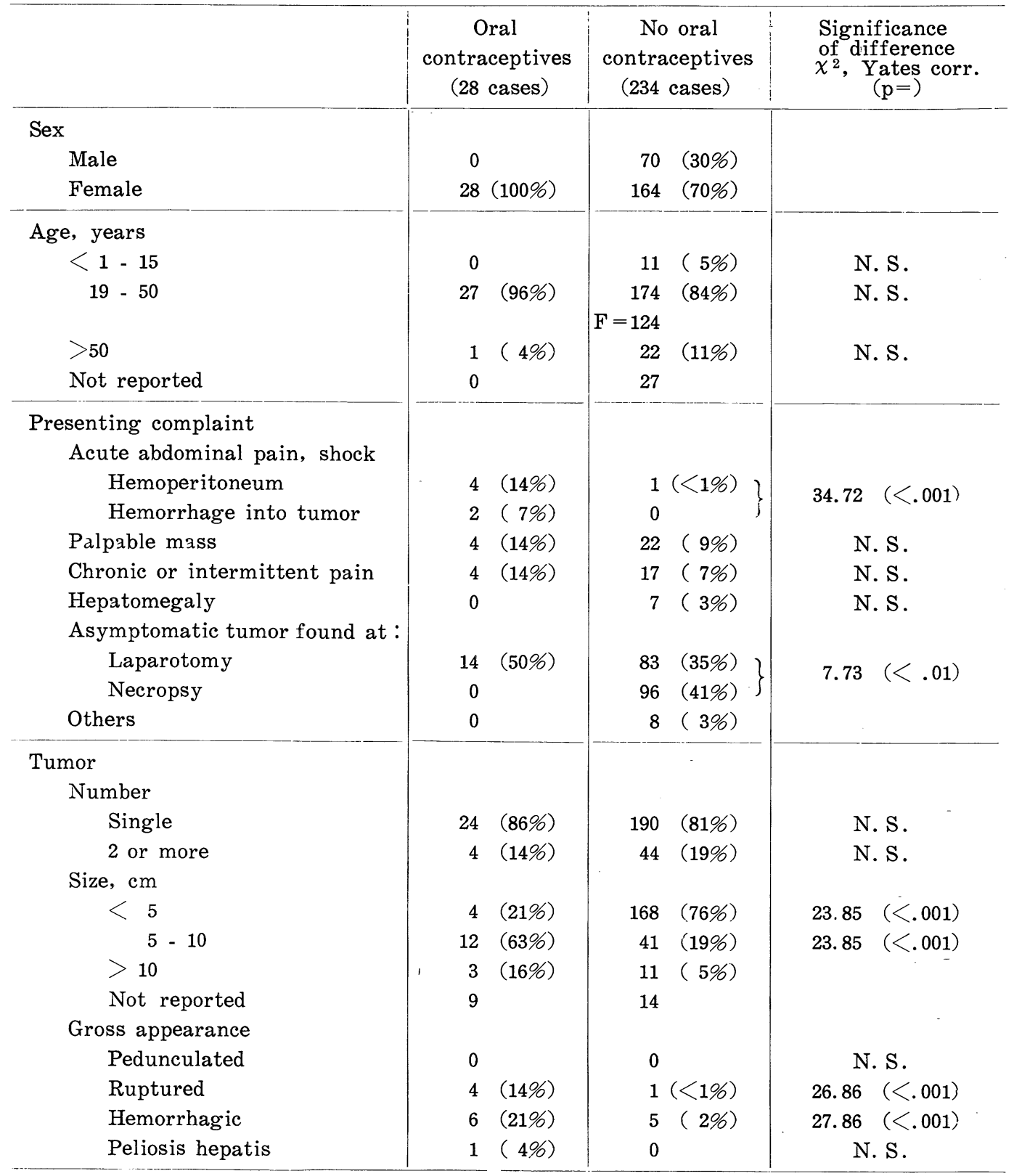


nusers. In contrast, five times as many tumors in the nonuser group were asymptomatic and found unexpectedly at laparotomy or necropsy.

As shown in Table 7, the hepatic cell adenomas associated with oral contraceptives tended to be larger than in the nonuser group. However, the most impressive difference was the significantly higher incidence of rupture, hemorrhage and peliosis hepatis in the former. Also notable was the greater frequency of sinusoidal dilatation and thick-walled vessels in patients on oral contraceptives.

In the case of focal nodular hyperplasia, there were equally impressive differences between those in users and nonusers (Table 8). Of particular note, acute abdominal pain due to either tumor rupture and hemoperitoneum or hemorrhage into the tumor was the presenting complaint in almost a quarter of the users, whereas it was rare in nonusers. In contrast, three-quarters of the tumors in nonusers were asymptomatic and discovered unexpectedly at laparotomy or necropsy.

As shown in Table 8, the size of the tumor in focal nodular hyperplasia tended to be larger in users than in nonusers of oral contraceptives. Of particular note was the significantly higher incidence of rupture, hemorrhage, sinusoidal congestion and peliosis hepatis in the users. In contrast, the tumors in nonusers contained a fibrous core and thick-walled vessels more frequently than those in nonusers of oral contraceptives.

These differences suggest that oral contraceptives may affect the vasculature of hepatic tumors. Indeed, this appears to be the case. As noted by others, all 3 of the "pill"-associated hepatic cell adenomas that I have studied exhibited significantly patchy congestion of the sinusoids (Fig. 26).
However, in addition, 2 of the cases had numerous unusual vascular lesions leading to peliosis hepatis, infarction and fibrosis. As illustrated in Fig. 27, the earliest lesion in these cases was an eccentric hemorrhage around a thinwalled vein resulting in displacement

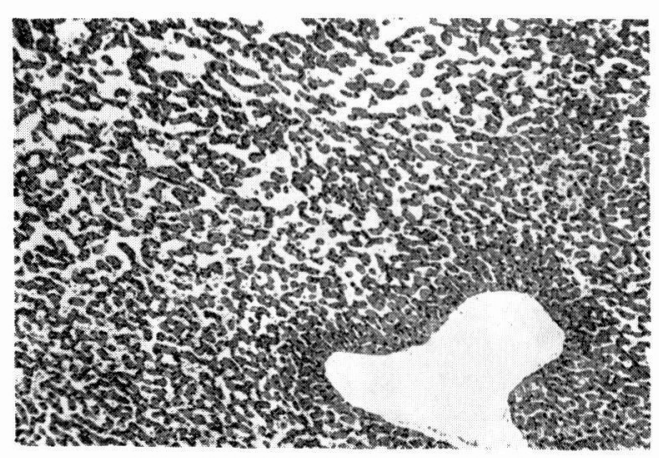

Fig. 26

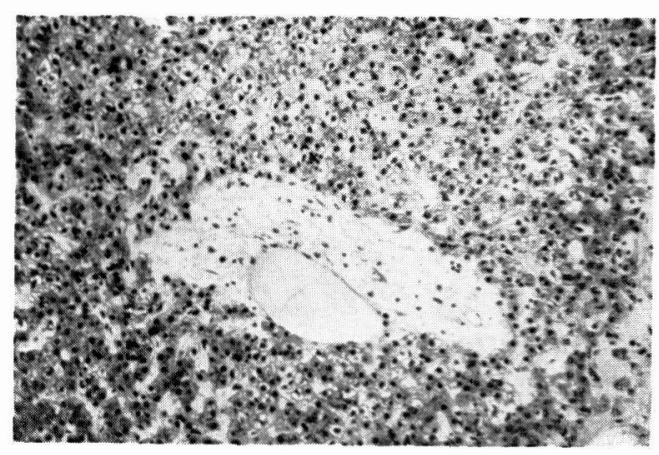

Fig. 27

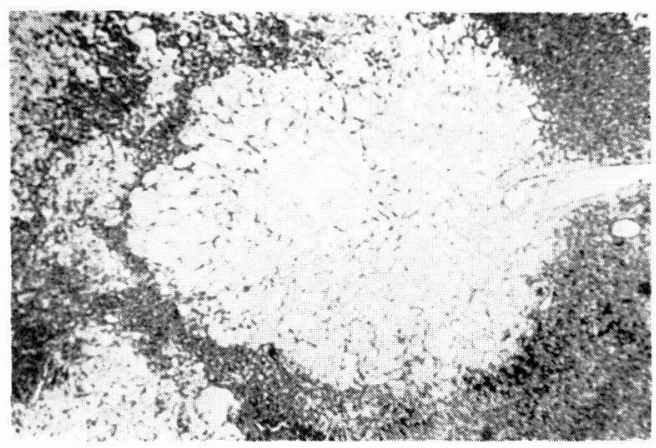

Fig. 28 
or dissolution of adjacent tumor cells. In more advanced lesions, the hemorrhagic zone encircled the vein (Fig. 28), ultimately producing cyst-like cavitiez typical of peliosis hepatis (Fig. 29). As illustrated in Fig. 30, some of the larger areas of hemorrhage showed evidence

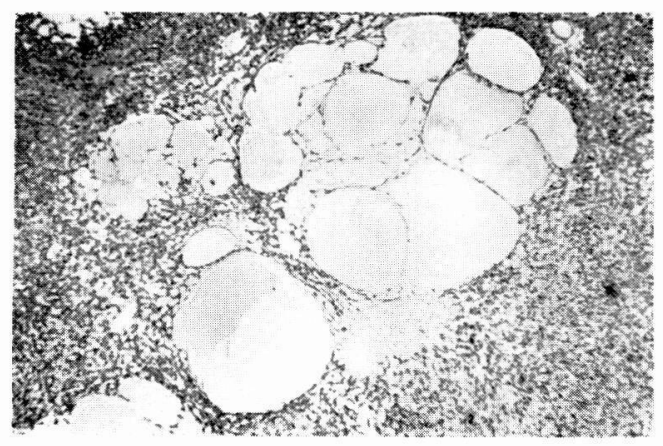

Fig. 29



Fig. 30

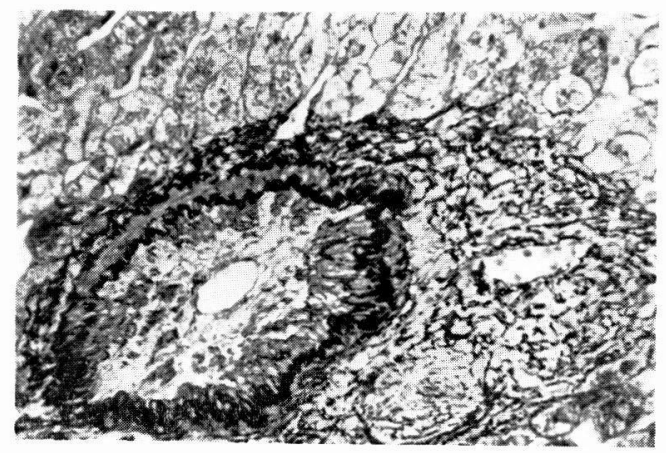

Fig. 31 of organization and fibrosis. The second type of vascular lesion was characterized by subintimal fibrosis and medial hypertrophy in arterioles resulting in constriction of their lumens (Fig. 31), and, in some instances, the development of infarction (Fig. 32).

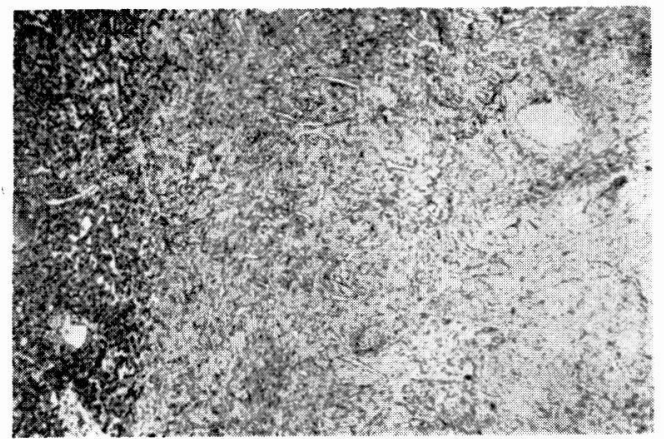

Fig. 32

There is suggestive evidence that oral contraceptives may affect normal liver tissue as well. Thus, in 4 women on oral contraceptives, Winkler and Poulsen (Winkler and Poulsen, 1975), observed hepatomegaly and significant periportal congestion, which in 3 cases appeared to resede following cessation of therapy. In another case, reported by Pliskin (Pliskin, 1975), hepatic arteriography revealed numerous focal accumulations of contrast material scattered through the liver, which appeared in the late arterial phase and became more prominent during the parenchymal and venous phases. These were interpreted as evidence of peliosis hepatis, although wedge biopsy of the liver showed only slight dilatation of the sinusoids.

One of our own patients on oral contraceptives presented with hepatomegaly. Scanning confirmed the enlagement, but revealed no defects. In contrast to Winkler and Poulsen's experience (Winkler and Poulsen, 1975), 
biopsy revealed sinusoidal congestion that was clearly midzonal in distribution (Fig. 33) and accompanied, in some areas, by focal hepatocellular atrophy and perisinusoidal fibrosis (Fig. 34). An additional finding of interest was an increase in the number and size of

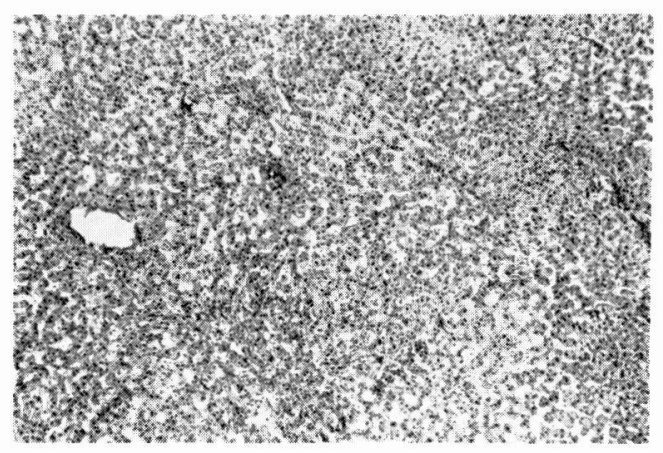

Fig. 33

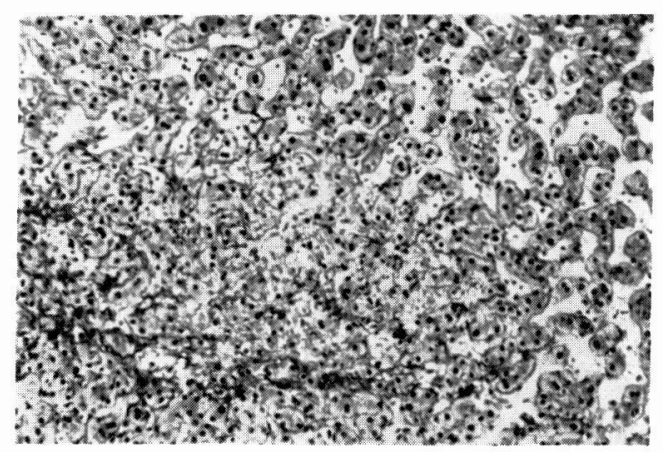

Fig. 34

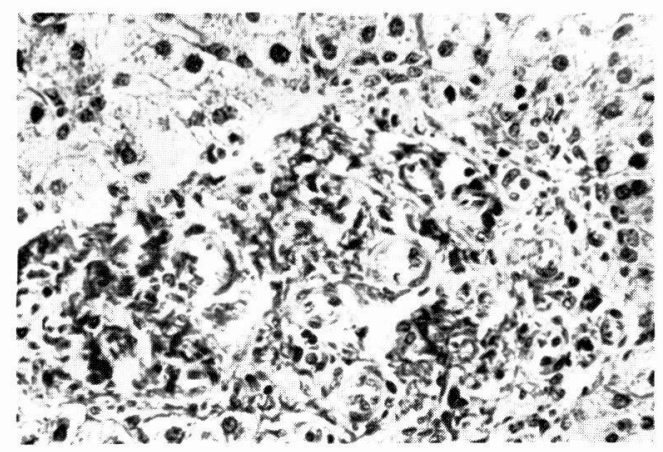

Fig. 35 the arterioles in many portal triads (Fig. 35). On hepatic angiography, the arterial vasculature appeared normal (Fig. 36). However, during the parenchymal and venous phases, numerous collections of contrast material, similar to those interpreted by Pliskin (Pliskin, 1975) as peliotic lesions, were found scattered throughout the right lobe (Fig. 37). In one area, there was a denser, more homogeneous and sharply circumscribed collection of contrast medium that suggested the presence of

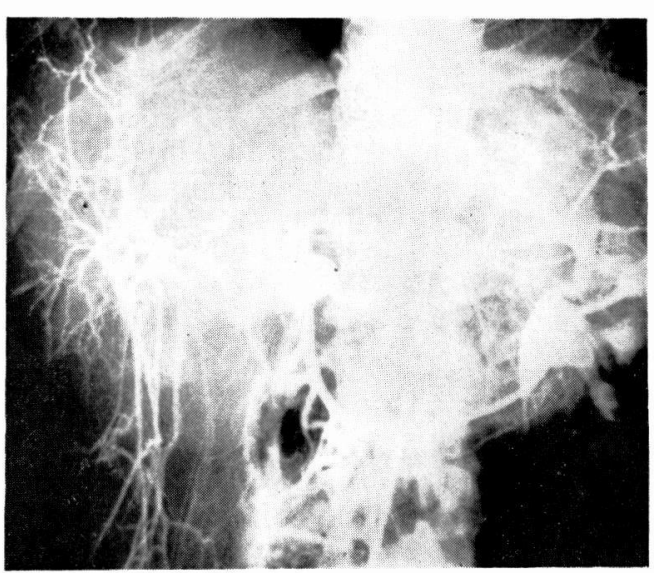

Fig. 36

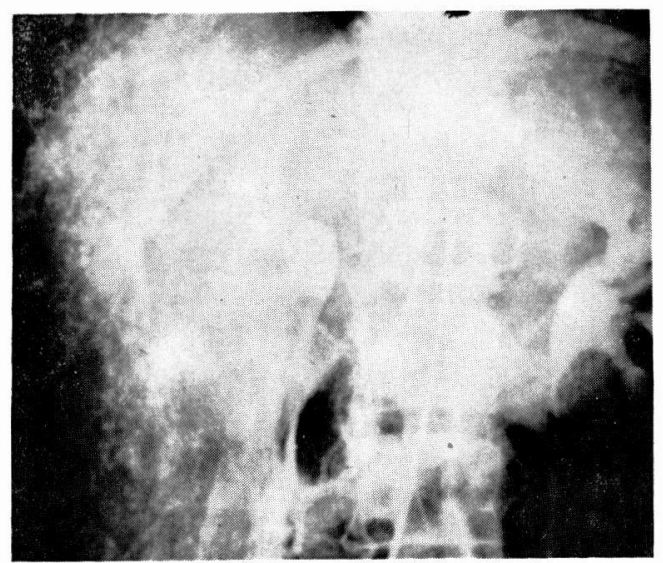

Fig. 37 
a small adenoma. At laparotomy, numerous small bluish areas were noted on the surface of the liver, but no frank peliotic lesions or tumor could be identified.

Although observations such as these suggest that oral contraceptives may produce vascular lesions in normal liver tissue, the specificity of such lesions has not been established by study of adequate controls. Indeed, in one of our patients with a large area of focal nodular hyperplasia in the left lobe, who had never used oral contraceptives, the right lobe showed evidence of congestion on biopsy (Fig. 38), and numerous collections of contrast medium suggestive of peliotic lesions during the

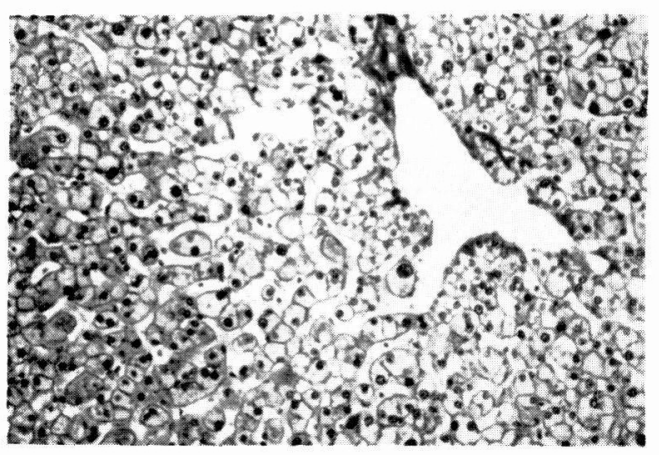

Fig. 38

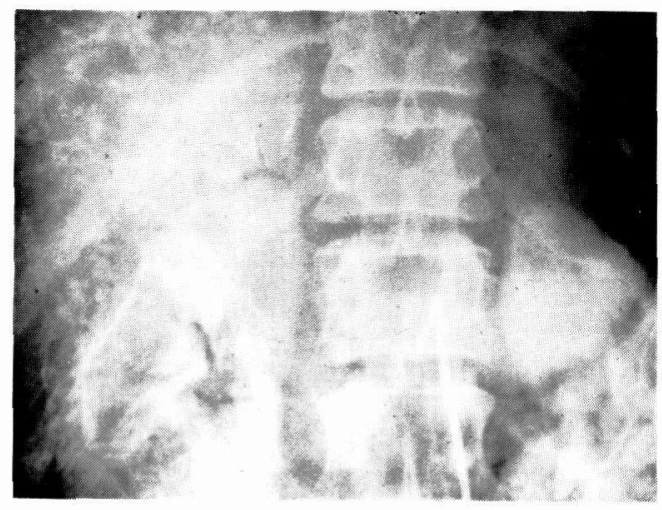

Fig. 39 venous phase of hepatic angiography (Fig. 39).

The last point to be considered is the critical question of whether or not currently available evidence warrants the conclusion that oral contraceptives are implicated in the pathogenesis of hepatic tumors. Although impressive, such evidence must be regarded as circumstantial rather than conclusive, so that the final answer to this question must await the results of future more comprehensive studies. Nevertheless, the evidence available at this time is sufficiently suggestive to merit review.

That hormonal factors may play a role in the pathogenesis of hepatic tumors is strongly suggested by the fact that approximately 80 percent of spontaneous hepatic adenomas and focal nodular hyperplasia are encountered in women of childbearing age (Tables 7 and 8), and that occasionally such tumors make their appearance during pregnancy (Grabowski et al., 1975 ; Malt et al., 1970 ; Motsay and Gamble, 1972 ; Schrager, 1937; Whelan et al., 1973; Mc Mullen and Montgomery, 1973) or the postpartum period (Berg et al., 1974; Christopherson and Mays, 1976; Malt et al., 1970). Other evidence pointing to such a relationship include reports of both benign and malignant hepatic tumors in patients with endocrine tumors, such as adenocarcinoma of the ovary (Grabowski et al., 1975) and carcinoma of the adrenal (O'Sulliva and Wilding, 1974), and in patients receiving various hormonal agents for purposes other than contraception, including conjugated natural estrogens (Christopherson, 1975 ; Christopherson and Mays, 1976), synthetic estrogens (Thallasinos et al., 1974; Sotaniemi et al., 1975) and synthetic androgenic-anabolic steroids (Johnson et al., 1972; Henderson and Richmond, 1973 ; Farrell et al., 1975., Mulvihill et al., 1975 ; Swe- 
eney and Evans, 1975). Of probable significance is the fact that all of these synthetic steroids, like those in oral contraceptives, are $\mathrm{C}_{17}$ alpha-alkyl derivatives of testosterone.

Considering that less than 400 cases of hepatic cell adenoma and focal nodular hyperplasia in non-"pill" users have been reported in English since 1937 (Tables 7 and 8), reports of over 200 cases in women on oral contraceptives in the part 3 years (Table 1) strongly suggests an etiological relationship.

However, relatively large numers of cases have been reported from four centers that have organized registries for hepatic tumors associated with oral contraceptives (Baum et al., 1973 ; Edmondson et al., 1976; Christopherson and Mays, 1976 ; Nissen et al., 1976). Obviously this introduces a bias in reporting that favors the relationship. Thus, of the 177 cases reported from these centers, 168 or $96 \%$ were "pill"-associated. Another potential source of bias that may inflate the number of cases identified stems from the failure of these registries to indicate whether or not any of their cases have been previously reported by others. What may be more realistic data on the relative frequency of benign hepatic tumors in users and nonusers of oral contraceptives have been reported from Sweden by Grabowski and his colleagues (Grabowski et al., 1975). These investigators, who reviewed all the biopsy and autopsy material in the files of the only hospital in Malmö, and the two major hospitals in Lund that together serve a population of over one and one-half million individuals, found that between 1964 and 1974, there were 8 cases of focal nodular hyperplasia in women of childbearing age, only 4 of whom had used oral contraceptives. Kay (Kay, 1976) suggests that the incidence may be even lower, since, in the 8 year prospective study of oral contraceptives being conducted by the Royal College of General Practioners in Great Britain, not one case of hepatic tumor has been encountered in women on the "pill", with a total exposure of 54,850 patient-years, or in any of their controls. Obviously a study of this type does not exclude the possibility of a relationship between oral contraceptives and hepatic tumors, but does suggest that, if these agents are oncogenic, they produce tumors only rarely.

Two clinical observations that suggest an etiological role for oral contraceptives are the regression of hepatic tumors following cessations of such therapy (Galloway et al., 1975 ; Stauffer et al., 1975 ; Ross et al., 1976) and the development of a second tumor at another site in the liver on continued use of oral contraceptives (Mays et al., 1976).

The results of animal experiments have been inconsistent. Thus, in strains of mice highly susceptible to spontaneous neoplasms, Enovid, a commonly employed oral contraceptive containing norethynodrel and mestranol, failed to increase the incidence of hepatic tumors, even when large doses were administered (Heston et al., 1973). However, in susceptible rats, a number of $\mathrm{C}_{17}$ alpha-alkyl derivatives of testosterone increased the expected frequency of liver-cell tumors. Since such agents are known to induce proliferation of the endoplasmic reticulum and the production of microsomal hydroxylating enzymes, it has been suggested that their oncogenic effect may be mediated by this adaptive process (Lingeman, 1974).

That the vascular changes in the hepatic tumors under consideration, particularly sinusoidal dilatation and peliosis hepatis (Tables 7 and 8) are attributable to the hormonal actions of oral contraceptives rather than the 
effects of the tumor is supported by several lines of evidence: (1) the occurrence of congestion and peliosis hepatis reported in individuals receiving synthetic androgenic-anabolic steroids closely related in structure to those used in oral contraceptives (Kintzen and Silny, 1960 ; Gordon et al., 1969 ; Mc Given, 1970 ; Naeim et al., 1973 ; Bagheri and Boyer, 1974 ; Groos et al., 1974), (2) the greater frequency of such vascular changes in the hepatic tumors of "pill"users than those of nonusers (Tables 7 and 8), (3) the occasional occurrence of bleeding and rupture in oral contraceptive-related tumors during menstruation (Edmondson, 1958), pregnancy (Stenwing and Solgaard, 1975) or the postpartum period (Antoniades and Brooks, 1975 ; Schenken, 1976 ; Christopherson and Mays, 1976), (4) the development in users of oral contraceptives of periportal and midzonal sinusoidal congestion (Winkler and Poulsen, 1975) or peliosis (Pliskin, 1975) in the absence of a hepatic tumor, or in association with a tumor, but located in an area distant from the tumor (Figs. 33 and 37), and, finally, (5) norethynodrel has been shown to produce dilatation of the sinusoids in female rats (Beaconsfield, 1974).

These observations raise the interesting question whether conceivably oral contraceptives merely enhance the growth rate of small otherwise unrecognized tumors. The frequency with which hepatic cell adenomas and focal nodular hyperplasia are found unexpectedly at laparotomy or necropsy in non-"pill" users (Tables 7 and 9) and the tendency of such tumors to be smaller in size than those associated with oral contraceptives (Tables 7 and 8) are consistent with this possibility.
However, to establish such a relationship will require a prospective systematic search for such tumors in a large consecutive series of necropsies on individuals whose use of oral contraceptives and other steroids can be documented.

The last two tables (Tables 9 and 10) summarize the evidence supporting a hormonal role in the pathogenesis of hepatic tumors, and evidence suggesting that vascular changes in hepatic tumors associated with oral contraceptives reflet hormonal effects, respectively.

In the last analysis, the question of whether or not oral contraceptives are oncogenic cannot be resolved until accurate data are available on the relative incidence of hepatic tumors in users and nonusers of such agents. Nothing short of a national registry of all hepatic tumors, including those encountered in both males and females and at all ages, can provide such information. In addition, such a registry would ensure accuracy in the classification of such tumors, and would give some indication of the magnitude of the problem, if one actually exists. Although a formidable and costly undertaking, health authorities would be well advised to organize such a registry as soon as possible, since the problem involved is a potentially serious one that will be of concern to millions of women, particularly once reports of hepatic tumors in users of oral contraceptives reach the public press, which they are bound to do. To reassure their patients and to provide sound advice on the risks involved, physicians will need more precise information on the oncogenic potential of oral contraceptives than is currently available. 
TABLE 9

Evidence supporting a hormonal role in the pathogenesis

of hepatic tumors

Spontaneous hepatic cell adenomas and focal nodular hyperplasia

$80 \%$ in women of child-bearing age

Appearance during pregnancy and postpartum period

Association with endocrine tumors

Adenocarcinoma of ovary

Carcinoma of adrenals

Following use of hormones for noncontraceptive purposes

Conjugated natural estrogens

$\mathrm{C}_{17}$ alpha-alkyl derivatives of testosterone

Synthetic estrogens

Synthetic androgenic-anabolic agents

Oral contraceptive-associated hepatic cell adenomas and focal nodular hyperplasia

Incidence

Spontaneous : $<400$ reported 1937-76

Oral contraceptive-associated : 223 reported 1972-76

Registry data: oral contraceptives/total cases

Baum $\quad 43 / 43$

Edmondson $\quad 29 / 34$

Christopherson $\quad 71 / 75$

Nissen 25/25

Total 168/177 (96\%)

Autopsy-biopsy data: Malmö and Lund, 1964-74

Grabowski $\quad 4 / 8 \quad(50 \%)$

Regression of tumors on cessation of oral contraceptives

Development of second tumor on continued "pill" use

Experimental

$\mathrm{C}_{17}$ alpha-alkyl steroids produce hepatic tumors in rats

TABLE 10

Evidence suggesting that vascular changes in hepatic tumors associated with oral contraceptives reflect hormonal effects

Congestion and peliosis in patients on $\mathrm{C}_{17}$ alpha-alkyl steroids

Vascular changes in hepatic tumors more common in users than nonusers of oral contraceptives

Hemorrhage and rupture of tumors during menstruation, pregnancy and postpartum period

Periportal congestion and peliosis in users of oral contraceptives in the absence of tumor, or in unaffected liver

Norethynodrel produces sinusoidal dilatation in female rats 
Presented at Hepatic Cancer meeting held in honor of Professor Toshiro Nakashima's 15th anniversary as Professor of Pathology at Kurume University, October 23, 1976, Kurume, Japan.

This paper was previously published in Gastroenterology and is reproduced here with the permission of the Editors of that journal.

\section{REFERENCES}

Albritton, D. R., Tompkins, R. K. and LongMIRE, W.P., Jr. (1974). Hepatic cell adenoma: a report of four cases. ANN. Surg., 180, 14-19.

Ameriks, J. A., Thompson, N. W., Frey, C. F., Appelman, H. D. and Walter, J. F. (1975). Hepatic cell adenomas, spontaneous liver rupture and oral contraceptives. Arch. Surg, 110, 548-556.

Antoniades, K. and Brooks, C. E., Jr. (1975). Hemoperitoneum from liver cell adenoma in a patient on oral contraceptives. Surgery, 77, 137-139.

Antoniades, K., Campbell, W. N., Hecksher, R. H., Kessler, W.B. and McCarthy, G. E. (1975). Liver cell adenoma and oral contraceptives: double tumor development. J.A. M. A., 234, 628-629.

Baek, S.-M., Sloane, C.E. and Fut terman, S. C. (1976). Benign liver cell adenoma associated with use of oral contraceptive agents. Ann. Surg., 183, 239-242.

BAgheri, S. A. and Boyer, J.L. (1974). Peliosis hepatis associated with androgenic-anabolic steroid therapy: a severe form of hepatic injury. Ann. Intern. Med., 81, 610618.

BARnes, A.C. (1976). Liver-cell adenomas and oral contraceptives. New Engl. J. Med., 294, 1061.

Bartók, I, Garas, S. and Szabó, L. (1976). Oral contraceptives and benign liver tumour. Lancet, 1, 479-480.

Baum, J. K. Holtz, F, Bookstein, J. J. and KLeIN, E. W. (1973). Possible association between benign hepatomas and oral contraceptives. Lancet, 2, 926-929.

BAUM, J. K. (1975). Liver tumors and oral contraceptives. J.A. M. A., 232, 1329.
BeAconsfield, P. (1974). Liver tumours and sterold hormones. Lancet, 1, 516-517.

BEGG, C.F. and BERRY, W.H. (1953). Isolated nodules of regenerative hyperplasia of the liver: the problem of their differentiation from neoplasm. Am. J. Clin. Path, 23, 447-463.

Benson, C. D. and Pemberthy, G. C. (1942). Surgical excision of primary tumor of liver (hamartoma) in infant seven months old with recovery. Surgery, 12, 881-886.

BenZ, E. J. and Baggenstoss, A. H. (1953). Focal cirrhosis of the liver: its relation to the so-called hamartoma (adenoma, benign hepatoma). Cancer, 6, 743-755.

Berg, J.W., KetelaAr, R. J., Rose, E.R. and Vernon, R. G. (1974). Hepatomas and oral contraceptives. Lancet, 2, 349-350.

Berkheiser, S. W. (1959). Recurrent liver cell adenoma. Gastroenterology, 37, 760-765.

Bisson, A., Duron, J.J., Fagniez, P.L., PinauDEAU, Y. and Germain, A. (1974). Adenomatose hepatique et contraceptifis oraux.

Nouv. Presse Med., 3, 2079-2082.

BLOCK, G. E. (1975). Discussion of paper by Ameriks J. A. et al (10). Arch. Surg. 110, 556-557.

Christopherson, W. M. (1975 a). Liver tomours and the pill. Br. Med. J., 4, 756.

Christopherson, W.M., Mays, E. T. and BarRows, G. H. (1975 b). Liver tumors in women on contraceptive ateroids. Obstet Gynec., 46, 221-223.

Christopherson, W.M. and MAys, E.T. (1976). Liver tumours and oral contraceptives. Lancet, 1, 1076.

Contostavlos,D.L. (1973). Benign hepatomas and oral contraceptives. Lancet, 2, 1200.

Davis, J.B., Schenken, J.R. and Zimmerman, O. (1973). Massive hemoperitoneum from rupture of benign hepatocellular adenoma. Surgery, 73, 181-184. See Schenken.

Davis, M., Portmann, B., Searle, M., Wright, R. and Williams, R. (1975). Histological evidence of carcinoma in a hepatic tumor associated with oral contraceptives. Br. Me. J., 4, 496-498.

Duckett, J. W. and Montgomery, H. G. (1947). Resection of primary liver tumors. Surgery, 21, 455-469.

Edmondson, H. A. (1958). Tumors of the Liver. Washigton, D. C. Armed Forces Institute of Pathology. 
Edmondson, H. A., Henderson, B. and Benton, B. (1976). Liver cell adenoma associated with use of oral contraceptives. New Engl. J. Med., 294, 470-472.

EvRARD, J.R. (1976). Liver-cell adenomas and oral contraceptives. New Engl. J. Med., 294, 1061.

Farrell, G. C., Joshua, D. E., URen, R. F., Baird, P. L., Perkins, K. W. and KronenBERG, H. (1975). Androgen-induces hepatoma. Lancet, 1, 430-431.

Fisher, A. W. F., Curry, B. and Jacques, J. (1975). Solitary liver nodules. Canada M. A. J., 112, 1196-1200.

Franklin, R. G. and Dowing, C. F. (1947). Primary liver tumors. Am. J. Surg., 73, 390-395.

Galloway, S. J., Casarella, W. J., Lattes, R. and Seaman, W. B. (1975). Minimal deviation hepatoma: a new entity. Am. J. Roentgenol. Rad. Therapy \& Nuclear Med, 125, 184-192.

Garancis, J. C., TAng, T., Panares, R. and JuREVICS, I. (1975). Hepatic adenoma: biochemical and electron microscopic study. Cancer, 24, 560-568.

Gerding, W. J., Popp, M. F. and Martineau, P. C. (1951). Hamartomatous cholangiohepatoma : report of a case. J.A.M.A., 145, 821-822.

Glassberg, A. B. and Rosenbaum, E.H. (1976). Oral contraceptives and malignant hepatoma. Lancet, 1, 479.

Goldstein, H. M., Neiman, H. L., Mena, E., Bookstein, J.J., Appelman, H.D., Mc Mullen, C. T. and Montgomery, L. (1974). Angiographic findings in benign liver cell tumors. Radiology, 110, 339-343.

Gordon, B.S., Wolf, J., Krause,T. and Shai,F. (1969). Peliosis hepatis and cholestasis following administration of norethandrolone. Am. J. Clin. Path., 33, 156-165.

Grabowski, M., Stenram, U. and Berqvist, A. (1975). Focal nidular hyperplasis of the liver, benign hepatomas, oral contraceptives and other drugs affecting the liver. Acta Path. Micrabiol. Scand. Sect. A., 83, 615-622.

Groos, G., Arnold, O. H. and Brittinger, G. (1974). Peliosis hepatis after long-term administration of oxymethalone. Lancet, $1,874$.

HaUschild, W. A. (1975). Benign hepatoma and oral contraceptives. Wisc. M. J., 74. 113.
Henderson, J. T. and Richmond, J. (1973). Androgenic-anabolic steroid therapy and hepatocellular carcinoma. Lancet, 1, 934.

Henson, S.W. Jr., Gray, H.K. and Dockerty, M.B. (1956). Benign tumors of the liver: 1. adenomas. Surg. Gynec. Obstet., 103, 23-30.

Hermann, R.E. and David, T.E. (1973). Spontaneous rupture of the liver caused by hepatomas. Surgery, 74, 715-719.

Heston, W. E., Vlahakis, G. and Desmukes, B. (1973). Effects of the antifertility drug Enovid in five strains of mice, with particular regard to carcinogenesis. J. Natl. Cancer Inst., 51, 209-224.

Hoffman, H. S. (1942). Benign hepatoma: review of the literature and report of a case. Ann. Intern. Med., 17, 130-139.

Horvath, E., Kovacs, K. and Ross, R.C. (1972). Ultrastructural findings in a well-differentiated hepatoma. Digestion, 7, 74-82.

Horvath, E., Kovacs, K. and Ross, R. C. (1974). Benign hepatoma in a young woman on contraceptive steroids. Lancet, $1,357-358$.

Hunter, W. R. (1949). A case of benign hepatoma. Brit. J. Surg., 36, 425-428.

IsHAK, K.G. and RABIN, L. (1975). Benign tumors of the liver. Med. Clinics N. Amer. 59, 995-1013.

JAGER, B. V. and Nugent, C. A. (1958). Solitary benign adenoma of the liver associated with progressive hepatic insufficiency: report of a case with autopsy findings. Arch. Intern. Med., 101, 645-649.

Johnson, F. L., Feagler, J. R., Lerner, K. G., Majerus, P. W., Siegel, M., Hartmann, J. and Thomas, E. D. (1972). Association of androgenic anabolic steroid therapy with development of hepatocellular carcinoma. Lancet, 2, 1273-1276.

KAY, S. and TAlbert, P. C. (1950). Adenoma of the liver, mixed type (hamartoma): report of two cases. Cancer, 3, 307-315.

KAY,S. and SchATZKI, P.F. (1971). Ultrastructure of a benign liver cell adenoma. Cancer, 28, 755-762.

KAY,C. R. (1976). Liver-cell adenomas and oral contraceptives. Lancet, 2, 52-53.

Kelso, D. R. (1974). Benign hepatomas and oral contraceptives. Lancet, 1, 315-316.

Kintzen, W. and Silny, J. (1960). Peliosis hepatis after administration of fluoxymesterone. Canad Med. Ass. J., 83, 860-862. 
Klatskin, G. Personal followup on case reported by Meyer, P.,et al.

KnApP, W.A. and Ruebner, B.H. (1974). Hepatomas and oral contraceptives. Lancet, 1, 270-271.

LARge, A. M. (1975). Discussion of paper by Ameriks, J. A., et al. Arch. Surg., 110, 557.

LARGiAdÉr, A. (1963). Leberzelladenoma ohne Zirrhose. Gastroenterologia, 99, 1-21.

LINGEMAN, C. H. (1974). Liver-cell neoplasms and oral contraceptives. Lancet, 1, 64 .

Littman, I., Berentey, E., Magyar, É. and BALÁZs, M. (1976). Anticoncpiiens, kezelés kapcsán letrejövó máj-adenoma operalt esete. Orvosi Hetilap, 117, 159-161.

Longmire, W.P., Jr. and MARABle, S. A. (1961). Clinical experiences with major hepatic resections. Ann. Surg., 154, 460-472.

Malt, R. A., Hershberg, R. A. and Miller, W. L. (1970). Experience with benign tumors the liver. Surg. Gynec. Obstet., 130, 285-291.

Mays, E.T., Christopherson, W.M. and BARRows, G.H. (1974). Focal nodular hyperplasia of the liver: possible relationship to oral contraceptives. Am. J. Clin. Path., 61, 735-746.

Mays, E. T., Christopherson, W. M., Mahr, M. M. and Williams,H.C. (1976). Hepatic changes in young women ingesting contraceptive steroids: hepatic hemorrhage and primary hepatic tumors. J.A.M.A., 235, 730-732.

McBurney, R.P., Woolner,L.B. and WollaeGER, E.E. (1950). Solitary hyperplastic nodule of the liver simulating a neoplasm: report of a case. Proc. Staff Meet Mayo Clinic., 25, 606-611.

McGiven, A. R. (1970). Peliosis hepatis: a case report and review of pathogenesis. J. Pathol., 101, 283-285.

Mcloughlin, M. J., Colapinto, R. F., Gilday, D. L., Hobbs, B. B., Korobkin, M. T., McDoNALd, P. and Phillips, M. J. (1973). Focal nodular hyperplasia of the liver: angiography and radioisotope scanning. Radio$\log \mathrm{y}, 107,257-263$.

McMullen, C.T. and Montgomery, J.L. (1973). Arteriographic findings of focal nodular hyperplasia of the liver and review of the literature. Am. J. Roentgenol. Rad. Therapy \& Nuclear Med., 117, 380-387.

Meyer, P., Li Volsi, V. A. and Cornog, J. L. (1974.). Hepatoblastoma associated with an oral contraceptive. Lancet, 2, 1387.
Model, D. G., Fox, J. A. and Jones, R. W. (1975). Multiple hepatic adenoma associated with an oral contraceptive. Lancet, 1, 865.

Motsay, G.J. and Gamble, W.G. (1972). Clinical experience with hepatic adenoma. Surg. Gynec. Obstet., 134, 415-418.

Mulvihill, J.J., Ridolfi, R.L., Schultz, F.R., Borzy, M.S., Haughton, P.B.T., Baltimore and Bethesda, Md. (1975). Hepatic adenoma in Fanconi anemia treated with oxymethalone. J. Pediat., 87, 122-124.

Naeim, F., Copper, P. H. and Semion, A. A. (1973). Peliosis hepatis: possible etiologic role of anabolic steroide. Arch. Pathol., 95, 284-285.

Nissen, E. D. and Kent, D. R. (1975). Liver tumors and oral contraceptives. Obstet. Gynec., 46, 460-467.

Nissen, E. D., Kent, D. R., Nissen, S. E. and Mc RAE, I. M. (1976). Association of liver tumors with oral contraceptives. Obstet. Gynec., 48, 49-55.

O Sullivan, J. P. and Wilding, R. P. (1974). Liver hamartomas in patients on oral contraceptives. Br. Med. J., 3, 7-10.

O Sullivan, J. P. and Rosswick, R. P. (1976). Oral contraceptives and malignant hepatic tumours. Lancet, 1, 1124-1125.

Packard, G. B. and Stevenson, A. W. (1974). Hepatoma in infancy and childhood: discussion and report of a patient treated by operation. Surgery, 15, 292-306.

Palubinskas, A. J., Baldwin, J. and Mc CorMACK, K. R. (1967). Liver cell adenoma : angiographic findings and report of a case. Radiology, 89, 444-447.

Phillips, M. J., Langer, B., Stone, R., Fisher, M.M. and Ritchie, S. (1973). Benign liver cell tumors : classification and ultrastructura; pathology. Cancer, 32, 463-470.

Pliskin, M. (1975). Peliosis hepatis. Radiology, 114, 29-30.

Ramchand, S., Suh,H.B. and Gonzales-Crussi, F. (1970). Focal nodular hyperplasia of the liver. Canad. J. Durg., 13, 22-26.

Ross, D., Pina, J., Mirza, M., Galvan, A. `and Ponce, L. (1976). Regression of focal nodular hyperplasia after discontinuation of oral contraceptives. Ann. Inter. Med., 85, 203-204.

Sackett, J. F., Mosenthal, W. T., House, R. K. and JEFFERY, R. F. (1971). Scintillation scanning of liver cell adenoma. Am. J. 
Roentgenol. Rad. Therapy \& Nuclear Med., $113,56-60$.

Schenken, J. R. (1976). Hepatocellular adenoma: Relationship to oral contraceptives ? J.A.M. A., 234, 559. See Davis et al.

Schrager, V. L. (1937). Surgical aspects of the liver. Ann. Surg., 105, 33-43.

SrORE, C. G. (1969). Spontaneous rupture of a hepatic adenoma: A possible hazard of flying. Brit. J. Surg., 56, 633-635.

ShoJAnia, N. G. and HogG, G. R. (1975). Isolated liver nodules. Gastroenterology, 69, 28-34.

Sotaniemi, E. A., Alavaikko, M. J. and KaipaINEM, W. J. (1975). Primary liver cancer associated with long-term oestrogen therapy. Ann. Clin. Res., 7, 287-289.

Stauffer, J.Q., LAPinski, M.W. Honols, D. J. and Myers, J.K. (1975). Focal nodular hyperplasia of the liver and intrahepatic hemorrhage in young women on oral contraceptives. Ann. Intern. Med., 83, 301-306.

Stenwing, A. E. and Solgaard, T. (1975). Ruptured benign hepatoma associated with an oral contraceptive : A case report. Virchow's Arch. A. Path. Anat. Histol, 367, 337-343.

StumpF, H. H. and Liber, F. L. (1954). Hepatocellular adenomatosis: report of a case with liver function studies. Am. J. Med., $17,887-890$.

Sweeney, E. C. and Evans, D.J. (1975). Liver lesions and androgenic steroid therapy. Lancet, 2, 1042.
Thallasinos, N.C., Lymberatos, C., HadjicanNoU, J. and Gardikas, C. (1974). Liver-cell carcinoma after long-term oestrogen-like drugs. Lancet, 1, 270.

Tigano, F., Ferlazzo, B. and Barrile, A. (1976). Oral contraceptives and malignant hepatoma. Lancet, 2, 196.

Tountas, C., Parskevas, G. and Deligeorgi, H. (1974). Benign hepatoma and oral contraceptives. Lancet, 1, 1351-1352.

Vosnides, G., Bewick, M., Brander, W., OgG,C. and O'KEEFFE, B. (1974). Liver hamartomas in patients on oral contraceptives. Br. Med. J., 3, 580 .

Whelan, T. J. Jr., BAUgh, J.H. and Chandor, S. (1973). Focal nodular hyperplasia of the liver. Ann. Surg., 177, 150-158.

Wilens, G. (1938). Adenoma of the liver. Am. J. Dis. Child., 55, 792-797.

Winkler, K. and Poulsen, H. (1975). Liver disease with periportal sinusoidal dilatatation: a possible complication to contraceptive steroids. Scand. J. Gastroent., 10, 699-704.

Carcinogenicity tests of oral contraceptives. A report by the Committee on the Safety of Medicines, London, 1972. Cited by C.H. Lingeman.

Clinicopathological Conferance: A patient's life. Br. Med. J., 3, 209-213. See Vosnides, et al. 